\title{
Bioturbation levels during the end-Ordovician extinction event: a case study of shallow marine strata from the Welsh Basin
}

\author{
Liam G. Herringshaw ${ }^{1, *}$, Neil S. Davies ${ }^{2}$ \\ ${ }^{1}$ Geology \& Petroleum Geology, School of Geosciences, Meston Building, University of Aberdeen, Aberdeen AB24 3UE, UK \\ ${ }^{2}$ Department of Earth Sciences, Dalhousie University, Halifax, Nova Scotia B3H 4J1, Canada
}

\begin{abstract}
The Ordovician-Silurian succession of the Llandovery area, mid-Wales, preserves shallow marine sediments deposited during the Hirnantian (end-Ordovician) extinction event. Ichnological analysis of the rocks shows that the degree and depth of bioturbation in this part of the Welsh Basin was often low across this interval, both during glacioeustatic sea level fall and the early part of the subsequent transgression. This pattern suggests that stratigraphic dilution was not the primary control on trace fossil abundance: an increase in sediment supply during the regression could explain low abundance in early Hirnantian units, but not in the post-glacial transgressive strata. A significant decrease in oxygen levels during sea level rise might be invoked instead, but this cannot have been the sole cause, as the occurrence of burrows up to $20 \mathrm{~mm}$ in diameter in the Bronydd Formation (late Hirnantian-Rhuddanian) shows that seafloor oxygen levels were at least intermittently high. An absence of vertical bioturbation through much of the succession indicates that sessile, suspensionfeeding organisms were generally scarce. The overall pattern probably reflects a decline in benthic infauna during the extinction event, but the 2 pulses of extinction described previously in body fossils are not evident ichnologically in this part of the Welsh Basin.
\end{abstract}

KEY WORDS: Ichnofabrics $\cdot$ Benthos $\cdot$ Infauna $\cdot$ Mass extinctions $\cdot$ Trace fossils

\section{INTRODUCTION}

The ecological effects of extinction events have typically been assessed using evidence from the body fossil record. However, the value of ichnology as a tool for measuring environmental stress, ecosystem restructuring and faunal recovery rate during such events is receiving increased recognition. Trace fossils have provided much new information on both the end-Permian (e.g. Twitchett \& Wignall 1996, Wignall et al. 1998, Twitchett 1999, Pruss \& Bottjer 2004, Pruss et al. 2004, Fraiser \& Bottjer 2005) and end-Cretaceous extinctions (e.g. Ekdale \& Bromley 1984, Ekdale \& Stinnesbeck 1998, Rodríguez-Tovar \& Uchman 2004a,b, RodríguezTovar 2005, Uchman et al. 2005). Of the other major Phanerozoic extinctions, however, the end-Ordovician event has seen scant ichnological study. Indeed, in their review of research into ichnological responses to mass extinctions, Twitchett \& Barras (2004) were able to cite only 1 published article (McCann 1990) examining trace fossils across the Ordovician-Silurian boundary. This dearth of work is surprising, since the extinction is associated intimately with perturbations of global climate and eustatic sea level and had a particularly severe effect on marine benthos. Ichnological studies, therefore, have the potential to provide greater understanding of ecological changes in the marine realm at that time, and also during extinction events in general.

Around $85 \%$ of marine species are estimated to have died out during the Late Ordovician extinction event (Brenchley et al. 2001, Sheehan 2001), which occurred in 2 phases, one at the beginning and one in the middle of the Hirnantian Age (see Fig. 1 in Brenchley et al. 2001). The first extinction pulse is correlated with a glacially forced regression that led to changes 
in nutrient cycling, and the second with post-glacial temperature and sea level rise and the stagnation of oceanic circulation (Sheehan 2001). The rapidity of the climate change is thought to have played a pivotal role in driving the extinctions (Brenchley et al. 1994, 2001). Few fossil groups suffered depletion in both extinction phases (Sheehan 2001), but, using brachiopod diversity as a proxy for ecosystem functioning, Brenchley et al. (2001) argued that, by the end of the second phase, benthic ecosystems had become 'severely disrupted and downgraded in complexity' and that faunal recovery took 4 to 5 million years. Ichnology provides a separate means for testing such hypotheses, using trace fossil diversity, burrow size, depth of bioturbation and ichnofabric index (sensu Droser \& Bottjer 1986, 1989) to assess the ecological response of benthic communities.

Ordovician-Silurian boundary strata are preserved in relatively few regions, and complete or nearcomplete successions through the extinction event are even scarcer. As such, the outcrops of the Welsh Basin are especially significant. The eastern margin of the basin, in the Llandovery area (Fig. 1), preserves a pre-

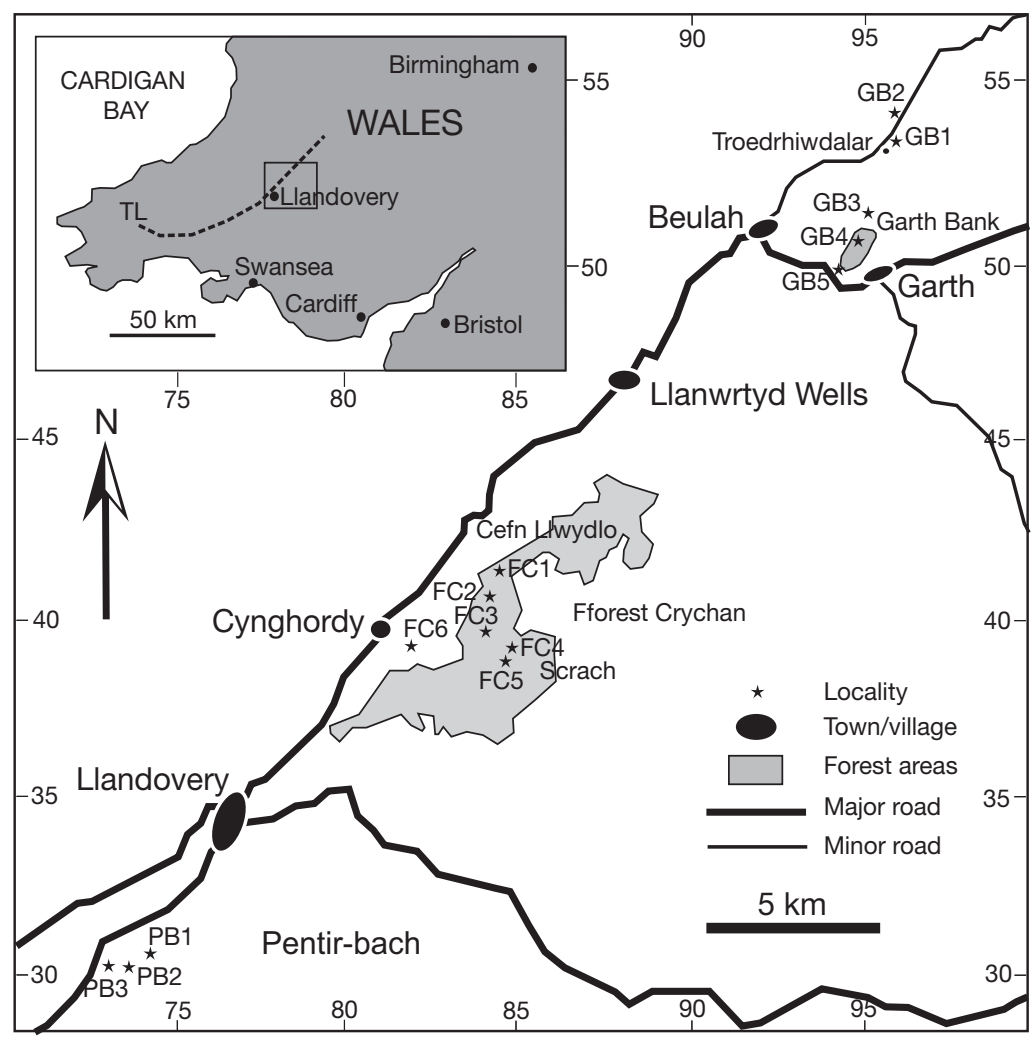

Fig. 1. Llandovery region, mid-Wales, with Garth Bank, Fforest Crychan and Pentir-bâch study areas and localities. Numbered $5 \mathrm{~km}$ grid squares are within the Ordnance Survey SN 100 km grid square. Regional map (inset) shows location of study area; dashed line: position of Tywi lineament (TL), a present-day representation of a fault-bounded slope separating shallower and deeper water parts of the Welsh Basin (Woodcock \& Smallwood 1987) dominantly nearshore succession spanning the endOrdovician extinction. Its ichnological complexity and diversity has never been examined in detail, and has the potential to provide much new information on the ecological effects of the extinction event. The only previous study of end-Ordovician trace fossils in the Welsh Basin (McCann 1990) focussed on deep marine ichnoassemblages of the Nereites ichnofacies rather than on shallow marine assemblages of the Skolithos or Cruziana ichnofacies. Although such deep marine ichnofaunas had become diverse by the Ordovician (Orr 2001), it is critical to establish the nature of ichnofabrics and trace fossils preserved in shallow marine environments, where the effects of glacioeustatic sealevel change would be more pronounced.

The present study is the first assessment of bioturbation levels and patterns in a nearshore succession from the Welsh Basin and focuses on end-Ordovician shelfal and nearshore deposits in the Llandovery/Llanwrtyd Wells area (Fig. 1). Typically, bioturbation depth and trace fossil diversity is greater in such shallow water settings, so a variation in these is potentially attributable to ecological change. However, a fall in sea level often results in increased sediment supply (see e.g. Einsele 1996). Schofield et al. (2004, p. 13; see also Davies et al. 1997) suggested that this phenomenon might have led to low levels of bioturbation in the Hirnantian strata of the Welsh Basin. To address this, bioturbation levels were examined not only in the sedimentary rocks laid down during the Hirnantian regression, but also in those deposited in the subsequent transgression. Low bioturbation levels in only the regressive part of the succession would support the stratigraphic dilution hypothesis, but their occurrence also in the transgressive strata would imply that other mechanisms were involved.

\section{LOCALITIES AND STRATIGRAPHY}

Following locality information published by Williams \& Wright (1981), Cocks et al. (1984), Woodcock \& Smallwood (1987) and Temple (1988), field work for the present study focused on 3 areas (Fig. 1): Garth Bank-Troedrhiwdalar, north of the village of Garth; Fforest Crychan, northeast of Llandovery; and Pentir-bâch, southwest of Llandovery. 
The geology of the Garth Bank area was described in detail by Williams \& Wright (1981), who studied around $450 \mathrm{~m}$ of late Ordovician and early Silurian marine mudstones and siltstones. They erected the Wenallt Formation (Rawtheyan-Hirnantian in age, max. $115 \mathrm{~m}$ thick); the Cwm Clŷd Formation (11 to $51 \mathrm{~m}$ thick), the lower part of which was dated as Hirnantian by the presence of the brachiopod Eostropheodonta hirnantensis; and the non-fossiliferous Garth Bank Formation (max. $77 \mathrm{~m}$ thick), interpreted as Rhuddanian in age. The transition between the Wenallt and Cwm Clŷd Formations was described as conformable in the northern part of the area, but increasingly unconformable towards the south (Fig. 2).

Cocks et al. (1984) examined the Ordovician-Silurian boundary stratigraphy of the type Llandovery area, including both Fforest Crychan and Pentir-bâch. They erected the Rawtheyan age Tridwr Formation, overlain by the Scrach Formation of Hirnantian age (stratigraphically equivalent to the Cwm Clŷd Formation of Williams \& Wright 1981; see also Woodcock \& Smallwood 1987 ) and the Rhuddanian age Bronydd and Crychan Formations. The maximum thickness of the Tridwr Formation was not specified, but the Scrach and Bronydd Formations were illustrated as being up to $150 \mathrm{~m}$ thick, and the Crychan Formation was shown to have a maximum thickness of $260 \mathrm{~m}$ (Fig. 2).

Subsequently, an Hirnantian fauna was identified from mudstones beneath the Scrach Formation in the Pentir-bâch area (Woodcock \& Smallwood 1987).

The regional stratigraphy was revised recently by the British Geological Survey (2005a,b; Schofield et al. 2004, Barclay et al. 2005) and is summarized in Fig. 3. The revised stratigraphy is also included in Fig. 2, with the thicknesses and ages of the described strata compared to those published by Williams \& Wright (1981) and Cocks et al. (1984). It should be noted, however, that the precise age of many of the formations is uncertain, depending on availability of palaeontological data. The base of the
Rhuddanian Stage (i.e. the Ordovician-Silurian boundary), for example, could only be defined as being 'at or near the base of the Bronydd Formation' by Cocks et al. (1984, p. 165).

The British Geological Survey retained the Tridwr Formation of Cocks et al. (1984), but described it as the lateral equivalent of a deeper water unit, the Nantmel Mudstones Formation, above which they erected the Cribarth Formation as the latest Rawtheyan unit. The earliest Hirnantian units are the contemporaneous, interdigitating Ciliau and Yr Allt Formations, representing shallower and deeper water conditions, respectively. As the sea level fell during the Hirnantian, coarser, shallow-water sediments were deposited in the eastern (nearshore) part of the region. Locally, in the Troedrhiwdalar and western Fforest Crychan areas, this is represented by the Cwmcringlyn Formation, which overlies the Ciliau Formation (Fig. 2). Pentirbâch is part of the Llandovery sheet (E212) and has yet to be revised by the British Geological Survey; their subdivision of the Hirnantian rocks there is not known. The Cwmcringlyn Formation was, however, described by Barclay et al. (2005, p. 3) as equivalent to the lower part of the Scrach Formation of Cocks et al. (1984) and Woodcock \& Smallwood (1987). Above the Cwmcringlyn Formation are the Cwm Clŷd Sandstone Forma-
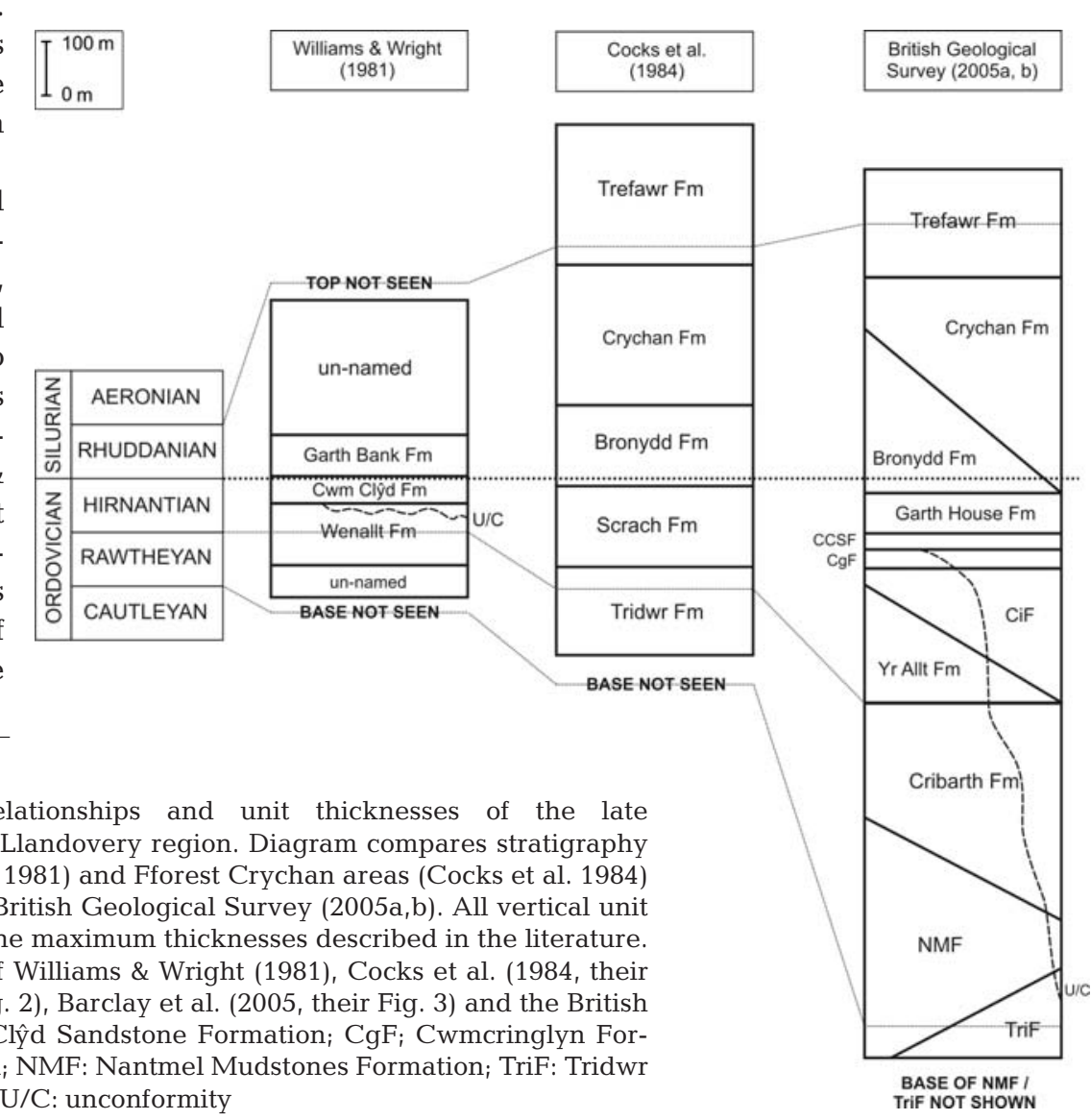

Fig. 2. Stratigraphical nomenclature, relationships and unit thicknesses of the late Ordovician-early Silurian succession of the Llandovery region. Diagram compares stratigraphy of Garth-Troedrhiwdalar (Williams \& Wright 1981) and Fforest Crychan areas (Cocks et al. 1984) with regional stratigraphy produced by the British Geological Survey (2005a,b). All vertical unit thicknesses are of the same scale, showing the maximum thicknesses described in the literature. Stratigraphic columns compiled from data of Williams \& Wright (1981), Cocks et al. (1984, their Figs. 1, 4, 69), Schofield et al. (2004, their Fig. 2), Barclay et al. (2005, their Fig. 3) and the British Geological Survey (2005a,b). CCSF: Cwm Clŷd Sandstone Formation; CgF; Cwmcringlyn Formation; CiF: Ciliau Formation; Fm: formation; NMF: Nantmel Mudstones Formation; TriF: Tridwr Formation; U/C: unconformity 
tion, a shoreface unit of maximum $30 \mathrm{~m}$ thickness, which is restricted to the Garth Bank and eastern Fforest Crychan areas, and then the thicker, transgressive Garth House Formation (Figs. 2 \& 3). Based on the outcrops mapped by the British Geological Survey (2005a,b), the Garth House Formation encompasses both the upper part of the Scrach Formation and the Garth Bank Formation of Williams \& Wright (1981), although this was not stated explicitly. For the uppermost Hirnantian-lower Rhuddanian part of the succession, the Bronydd and Crychan Formations (Cocks et al. 1984) were retained, with deep-water strata to the west being placed in the Tycwtta Mudstones and Chwefri Formations (see Fig. 3). Broadly speaking, the strata form a conformable succession in the northern and western parts of the region, but become unconformable towards the south and east (see Fig. 3 for details).

Given that the present study was concerned with ichnological changes in shelf and nearshore sedi- ments, the distal, basinal units of the successionNantmel Mudstones Formation, Yr Allt Formation, Tycwtta Mudstones Formation and Chwefri Formation-were not examined in detail. Outcrops of the more proximal units examined in this study occur mostly in road- or track-side cuttings, particularly in the Forestry Commission-managed areas of Garth Bank and Fforest Crychan. However, many of the localities documented by Williams \& Wright (1981), Cocks et al. (1984) and Woodcock \& Smallwood (1987) have since degraded considerably. The specific localities/transects studied, shown geographically in Fig. 1 and stratigraphically in Table 1 and Fig. 3, are as follows:

(1) Garth Bank area. GB1, road cutting east of Troedrhiwdalar chapel [SN 953 533]; GB2, road cutting north of Pen-rhiw-dalar farm [SN 956 537]; GB3, roadside outcrop at Dolderwen [SN 949 513]; GB4, disused quarry at Cwm Clŷd, Garth Bank [SN 947 509]; GB5, disused quarry just north of Garth House Farm [SN 943 499].

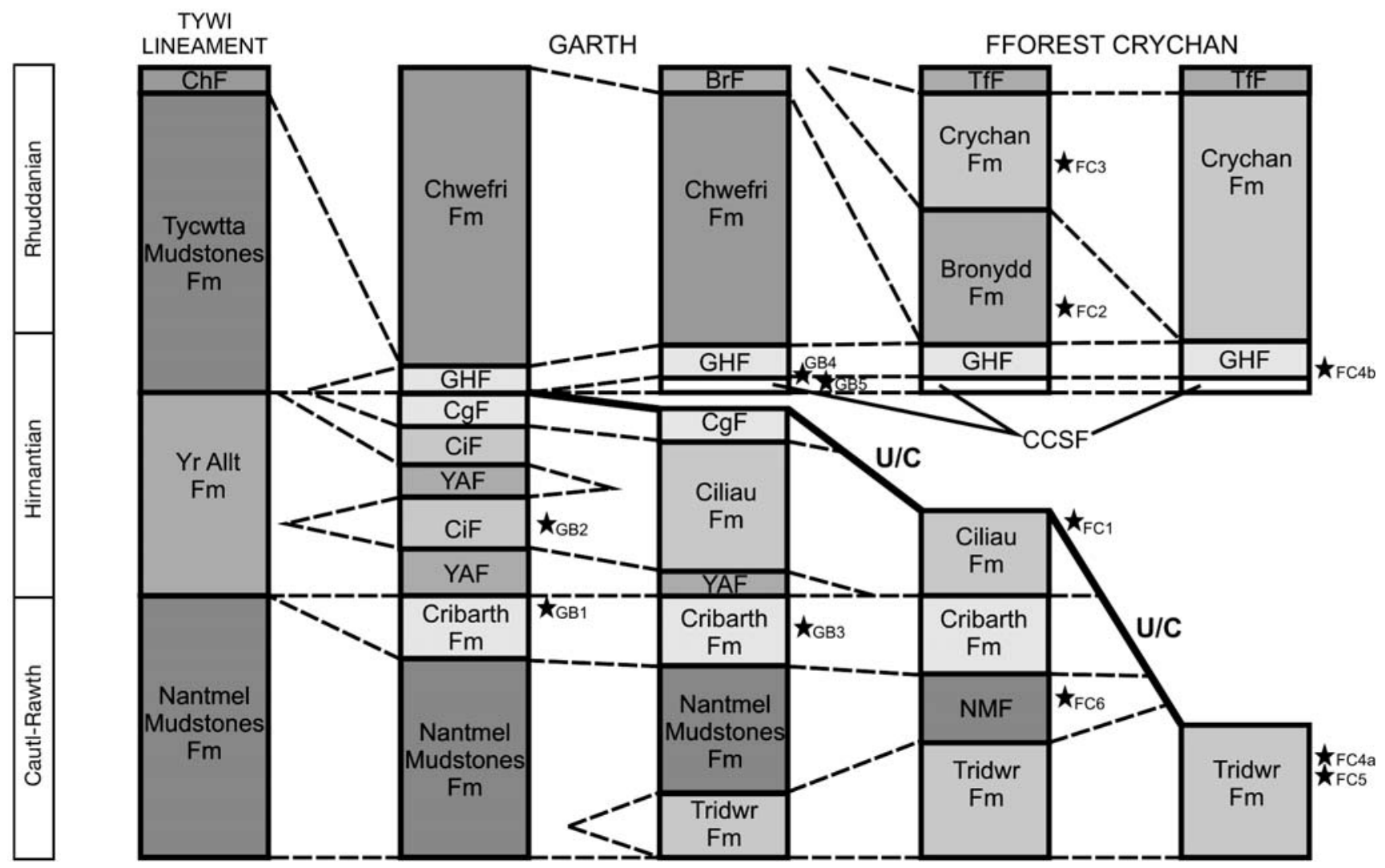

Fig. 3. Stratigraphical relationships of the late Ordovician and early Silurian succession of the Llandovery region, modified from Schofield et al. (2004, their Fig. 2) and Barclay et al. (2005, their Fig. 3). Vertical and lateral changes in unit thicknesses generalized for clarity; spacing between columns does not represent true distances between study areas (see Fig. 1 for locations of Tywi lineament, Garth and Fforest Crychan). Localities in Pentir-bâch are not shown, as revised stratigraphy for the region has not yet been published by the British Geological Survey: see Table 1 for details. BrF: Bronydd Formation; CgF: Cwmcringlyn Formation; ChF: Chwefri Formation; CiF: Ciliau Formation; CCSF: Cwm Clŷd Sandstone Formation; Fm: formation; GHF: Garth House Formation; NMF: Nantmel Mudstones Formation; TfF: Trefawr Formation; YAF: Yr Allt Formation; U/C: unconformity; $\star$ stratigraphic position of localities shown in Fig. 1 
Table 1. Stratigraphical nomenclature and geological ages of localities studied (after Schofield et al. 2004, Barclay et al. 2005). Refer to Fig. 1 for geographical details. Fm: formation

\begin{tabular}{|lll|}
\hline Locality & Unit/s present & Age \\
\hline FC3 & Crychan Fm & Rhuddanian \\
PB1, FC2 & Bronydd Fm & Early Rhuddanian \\
FC4b & Garth House Fm & Late Hirnantian \\
GB4 & Cwm Clyd Sandstone Fm/ & Mid- to late \\
& Garth House Fm & Hirnantian \\
GB5 & Cwm Clyd Sandstone Fm & Mid-Hirnantian \\
PB2, PB3 & Scrach Fm (= lower & Mid-Hirnantian \\
& Cwmcringlyn Fm) & Early Hirnantian \\
FC1, GB2 & Ciliau Fm & Late Rawtheyan \\
GB1, GB3 & Cribarth Fm & Rawtheyan \\
FC4a, FC5 & Tridwr Fm & Rawtheyan \\
FC6 & Nantmel Mudstones Fm & \\
\hline
\end{tabular}

(2) Fforest Crychan area. FC1, road cutting at junction of main road with track to Cefn Llwydlo [SN 8445 4120]; FC2, small quarry at the junction of 2 forestry tracks [SN 8455 4090]; FC3, small outcrop alongside forestry track at SN 8433 3987; FC4, 2 outcrops northeast of Scrâch farmstead [FC4a at SN 848 394, FC4b at SN 847 393]; FC5, outcrop southwest of Scrâch farmstead at SN 8473 3921; FC6, roadside outcrop SSW of Rhydins farm [SN 8155 3950].

(3) Pentir-bâch area. Transect carried out along public footpath from Lletty-Ifan-Ddu [Locality PB1, SN 7414 3038] via small quarry (PB2) at SN 73563019 to small exposure PB3 at SN 7333 3020, east of Glasalltfawr.

\section{RESULTS}

At each of the localities, the strata were examined for bioturbation, and the ichnofabric index (ii) was recorded in the field using the semi-quantitative classification scheme of Droser \& Bottjer (1986). For any dis- crete trace fossils present, their width and length were measured, as well as the depth to which they penetrated the substrate. Where bedding surfaces were not visible, the thicknesses of bioturbated intervals were measured. The data are summarized in Table 2. Only in the Ciliau (37 samples) and Bronydd (53 samples) Formations were discrete trace fossils found in sufficient numbers to enable median values of width and length to be calculated meaningfully.

\section{Rawtheyan strata}

The Tridwr Formation was examined at Localities FC4a and FC5 and the contemporaneous Nantmel Mudstones Formation at Locality FC6. The Nantmel Mudstones Formation at this locality consisted of finely laminated mudstones devoid of trace fossils (ichnofabric index $=1$ ); bioturbation was present in the interbedded dark grey silts and thin sands of the Tridwr Formation. At Locality FC5, Chondrites with a diameter of $1 \mathrm{~mm}$ was found with a maximum vertical extent of $14 \mathrm{~mm}$. Simple horizontal traces with a maximum diameter of $12 \mathrm{~mm}$ and length of $70 \mathrm{~mm}$ (Table 2) were restricted to discrete horizons at the base of thin sandstone beds. The overall ichnofabric index was measured as 2 to 3 .

Body fossils from the road cutting east of Troedrhiwdalar Chapel (Locality GB1) are late Rawtheyan in age (Williams \& Wright 1981). The rocks were assigned to the Cribarth Formation by the British Geological Survey (2005a), and the formation crops out also at Locality GB3. The mudstone beds are mostly homogeneous and up to $80 \mathrm{~mm}$ thick: thin bioturbated sands $(<3 \mathrm{~mm}$ thick) were seen occasionally, but no discrete trace fossils were found at either GB1 or GB3. Barclay et al. (2005, p. 4) described the unit as 'thoroughly mixed ... by pervasive bioturbation', an interpretation consistent with these observations. As such, an ichnofabric index of 5 is assigned to the unit.

Table 2. Ichnofabric index (ii), bioturbation depth (Max. BD) and trace fossil dimensions (in mm) observed in late Ordovician-early Silurian sediments of the Llandovery region. TrF: Tridwr Formation; CrF: Cribarth Formation; CiF: Ciliau Formation; CgF: Cwmcringlyn Formation; CCSF: Cwm Clŷd Sandstone Formation; GHF: Garth House Formation; BrF: Bronydd Formation; CcF: Crychan Formation

\begin{tabular}{|c|c|c|c|c|c|c|c|c|c|}
\hline \multirow[t]{2}{*}{ Unit } & \multirow[t]{2}{*}{ Age } & \multirow[t]{2}{*}{ ii } & \multirow{2}{*}{$\begin{array}{l}\text { Max. BD } \\
(\mathrm{mm})\end{array}$} & \multicolumn{3}{|c|}{ Trace fossil width (mm) } & \multicolumn{3}{|c|}{ Trace fossil length (mm) } \\
\hline & & & & Min. & Max. & Median & Min. & Max. & Median \\
\hline $\mathrm{CcF}$ & Rhuddanian & 2 & - & 1 & 7 & - & 4 & 14 & - \\
\hline $\mathrm{BrF}$ & Rhuddanian & $2-3$ & 5 & 1 & 20 & 2 & 8 & 50 & 14.5 \\
\hline GHF & Late Hirnantian & 2 & 5 & - & - & - & - & - & - \\
\hline $\mathrm{CCSF}$ & Mid-Hirnantian & 2 & 10 & - & 5 & - & - & - & - \\
\hline $\mathrm{CgF}$ & Mid-Hirnantian & $1-2$ & 6 & - & - & - & - & - & - \\
\hline $\mathrm{CiF}$ & Early Hirnantian & $2-3$ & 9 & 0.5 & 15 & 2 & 4 & 60 & 17 \\
\hline $\mathrm{CrF}$ & Late Rawtheyan & 5 & 80 & - & - & - & - & - & - \\
\hline $\operatorname{TrF}$ & Rawtheyan & $2-3$ & 14 & 1 & 12 & - & 7 & 70 & - \\
\hline
\end{tabular}




\section{Hirnantian strata}

The roadside exposure at Pen-rhiw-dalar (Locality GB2) belongs to the Ciliau Formation (British Geological Survey 2005a). Sand-filled vertical burrows with a diameter of 3 to $5 \mathrm{~mm}$ and horizontal burrows up to $50 \mathrm{~mm}$ long and $12 \mathrm{~mm}$ wide were found (Table 2), but were restricted to discrete layers of sand 2 to $9 \mathrm{~mm}$ thick, separated by unbioturbated dark grey silts of 4 to $6 \mathrm{~mm}$ thickness. An ichnofabric index of 2 to 3 is assigned to the Ciliau Formation, an observation supported by observations made at a larger exposure of the formation at Locality FC1, where horizontal bioturbation was dominant, consisting of 3 types: tiny chondriform features 0.5 to $1 \mathrm{~mm}$ wide and 8 to $12 \mathrm{~mm}$ long, arcuate to sub-arcuate burrows 1 to $7 \mathrm{~mm}$ wide and 25 to $30 \mathrm{~mm}$ long, and rare horn-shaped burrows up to $15 \mathrm{~mm}$ wide and $40 \mathrm{~mm}$ long (Table 2). No crosscutting relationships were seen, so it is unclear whether the traces were made simultaneously or sequentially. Very rare vertical to sub-vertical burrows up to $8 \mathrm{~mm}$ in diameter were found also, as well as occasional thin bioclastic layers containing crinoid ossicles, bryozoan and possible cephalopod fragments.

The Cwmcringlyn Formation was defined by Barclay et al. (2005, p. 3) as being equivalent to the lower part of the Scrach Formation: based on greater outcrop quality and accessibility, the Scrach Formation at Pentir-bâch was used to assess bioturbation at this stratigraphic level. At Locality PB2, the deposits consisted of very thinly laminated fine sands and organic-rich muds, with some evidence of minor disturbance $(<6 \mathrm{~mm}$ depth) by tracemakers. In the small exposure of grey sandstones at Locality PB3, bioturbation was not seen, giving the unit an overall ichnofabric index of 1 to 2 .

Evidence of bioturbation in the Cwm Clŷd Sandstone Formation was scarce. Rare vertical burrows (diameter $<5 \mathrm{~mm}$ ) were found in the formation at Locality GB5, as well as a single horizontal trace $10 \mathrm{~mm}$ in width and 100 $\mathrm{mm}$ in length, but the ichnofabric index was never greater than 2. No discrete trace fossils or other signs of bioturbation were found in the formation at Localities GB4 or FC4b. Similarly, no unequivocal bioturbation was seen in the Garth House Formation in the limited exposures accessible on Garth Bank (e.g. Locality GB4). However, at Locality FC4b in Fforest Crychan, a bioturbated, dark-grey mudstone bed $45 \mathrm{~mm}$ thick was found, the top of which is a thin, fine-grained sandstone layer in which possible fugichnial trace fossils of limited size ( $<5 \mathrm{~mm}$ vertical depth, 3 to $5 \mathrm{~mm}$ width) occur (see Fig. 4A,C). Fugichnia are traces produced by the vertical movement of benthos escaping a rapid inundation of sediment, and, in this case, may be the response to a pulse of sand burying a community that had established itself on or in the seafloor muds.

\section{Rhuddanian strata}

Of all the units studied, the greatest ichnological diversity was found in the Bronydd Formation at Localities PB1 and FC2. A variety of trace fossils was present, with relatively short, wide, sinusoidal traces of the ichnogenus Cochlichnus (Fig. 4B) and, where more meandering, possibly Helminthopsis (see e.g. Buatois et al. 1997 for discussion of morphological differences) and Planolites. Long, thin, straight trails were common also, along with short, straight, relatively wide traces, 1 specimen of which (Fig. 4D) has expanded lateral termini, suggesting it might be the basal view of a U-shaped burrow with spreiten, such as Diplocraterion. Bioturbation was most abundant in the sandier units of the formation at Locality PB1, where 6 specimens of Cochlichnus were found and other horizontal traces are common. The finer grained parts of the Bronydd Formation at PB1 and FC2 were bioturbated also, but, as with many of the older units, the traces were restricted to thin $(<2 \mathrm{~mm})$ sand laminae within unbioturbated silts and muds. The ichnofabric index of the unit is classified as 2 to 3 .

At Locality FC3, the Crychan Formation consisted of siltstone with bioturbated sandy laminae that yielded occasional cylindrical, horizontal burrows up to $7 \mathrm{~mm}$ in diameter and is assigned an ichnofabric index of 2 .

\section{DISCUSSION}

The low ichnofabric index recorded in most units (Table 2) suggests that, during the late Ordovician and early Silurian, oxygen levels in the Welsh Basin were often reduced at the sea floor. However, an ichnofabric index of 5 in the Cribarth Formation and the presence of burrows $>10 \mathrm{~mm}$ in diameter in the Tridwr, Ciliau and Bronydd Formations show that, at least periodically, they were sufficiently elevated to support relatively large bioturbators. Of the units with low indexes, the Cwmcringlyn, Cwm Clyd Sandstone and Garth House Formations are noteworthy, as they represent the shallowest water strata studied and, as such, might be expected to be well bioturbated. The lack of bioturbation seen in the Garth House Formation in this study contrasts with the findings of Williams \& Wright (1981, p. 15), who stated that the equivalent Garth Bank Formation had 'bedding planes...rich in trace fossils.' However, the bioturbation was not quantified, and the diversity of ichnotaxa was not discussed. Elsewhere, Barclay et al. (2005) described the Nantmel Mudstones Formation as typically mottled by bioturbation, but trace fossils were absent from the exposure at Locality FC6. These patterns may be the result of varying oxygen levels during deposition of the formations, but 

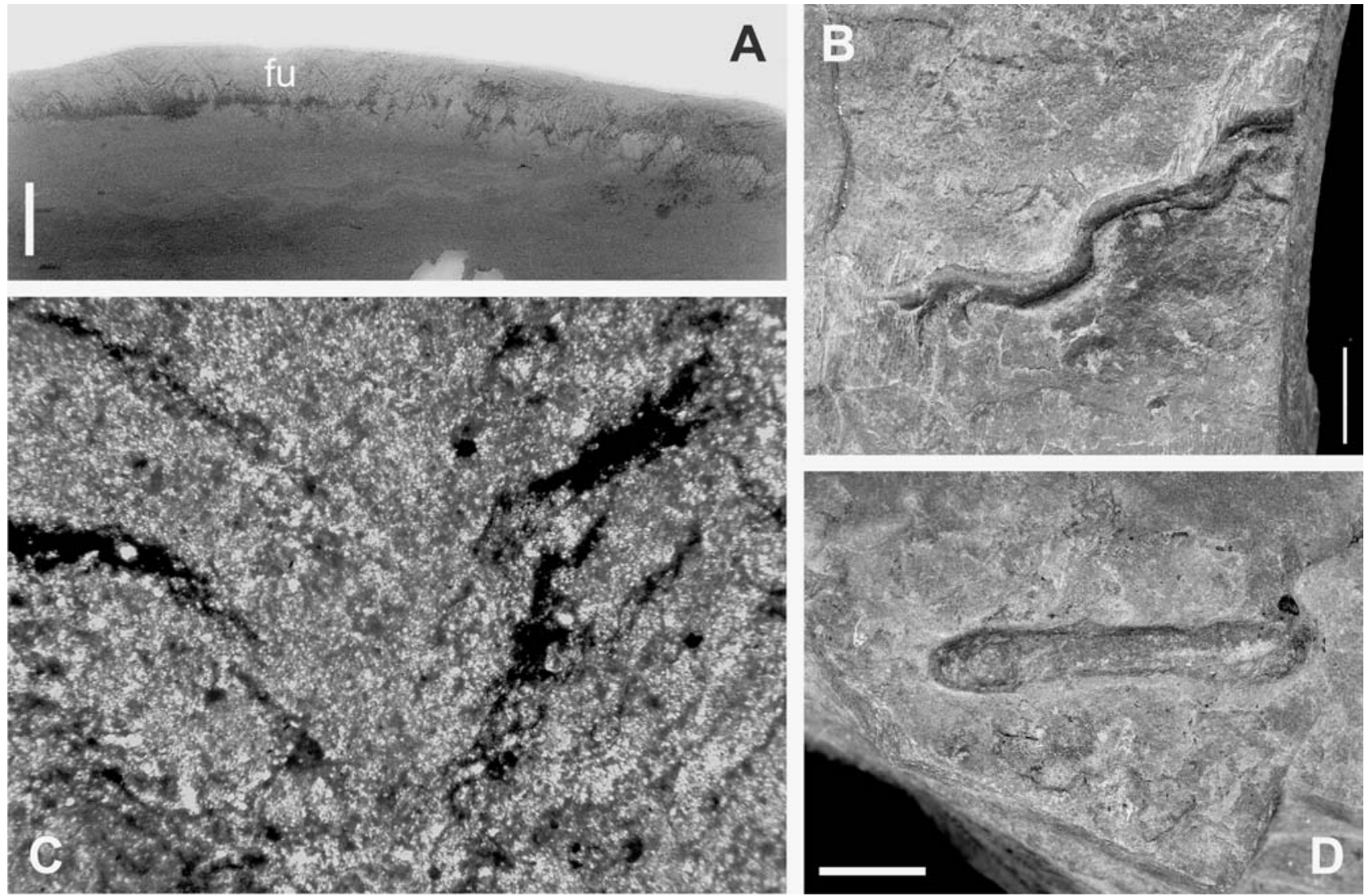

Fig. 4. (A, C) Possible fugichnial bioturbation in thin sand layer deposited on top of dark-grey mudstone, Garth House Formation, Locality FC4b, Fforest Crychan. (A) Thin section showing horizontally bioturbated mudstone overlain by sand layer with possible fugichnia (fu) producing chevron-shaped distortion of laminae; scale bar $=5 \mathrm{~mm}$. (C) Photomicrograph of chevron-shaped laminae within fugichnia; width of field of view $=2 \mathrm{~mm}$. (B, D) Trace fossils from the Bronydd Formation, Locality PB1, Pentir-bâch. (B) Cochlichnus isp.; scale bar $=5 \mathrm{~mm}$. (D) A short, straight, trace fossil with expanded lateral terminations; $\mathrm{scale}$ bar $=5 \mathrm{~mm}$

could also be an artefact of lateral ichnofabric variability. McIlroy $(2004,2007)$ demonstrated the patchiness of ichnofabrics within laterally continuous strata and emphasized the problem of correlating bioturbation patterns regionally; examination of end-Ordovician bioturbation across the Welsh Basin is required to determine the significance of this phenomenon.

The low levels of vertical bioturbation observed in the succession are significant. Schofield et al. (2004) described Skolithos as abundant in some parts of the Cwm Clŷd Sandstone Formation, indicating conditions suitable to a low-diversity community of suspensionfeeding vertical burrow-makers, but they have not been recorded from other nearshore units (Cwmcringlyn and Garth House Formations). Again, this might suggest reduced $\mathrm{O}_{2}$ levels, but shallow water deposits often accumulate rapidly and may be wave-reworked, reducing the preservation potential of tracemaker activity. Typically though, vertical trace fossils form a significant component of ichnofabrics in shallow marine settings, where higher energy conditions maintain large amounts of nutrients in suspension (Pember- ton et al. 2001). When ichnological diversity increases in the Rhuddanian (Bronydd Formation), the trace fossils are exclusively horizontal: their rarity through the succession suggests that conditions in the shallow marine realm of the Welsh Basin were often inimical to suspension-feeding taxa during the end-Ordovician extinction event.

One of the most distinctive aspects of the endOrdovician extinction is that a high proportion of species and genera disappeared, but few or no groups at ordinal level or above (Brenchley et al. 2001). Given that similar trace fossils can be made by unrelated organisms behaving in the same way (Ekdale et al. 1984, p. 18), correlating ichnological patterns with changes in body fossil diversity is inherently difficult. However, the fact that species and genera became extinct, rather than orders or classes, has led some workers to argue that changes in ecosystem functioning during and after the end-Ordovician extinction were relatively minor (see e.g. Droser et al. 1997). As such, there may not have been major changes in ichnological diversity and complexity. 


\section{SUMMARY}

(1) In this, the first ichnological study of shallow marine strata spanning the end-Ordovician extinction event, bioturbation levels in a succession from the Welsh Basin are shown to have commonly been low. This is interpreted as being caused primarily by a decline in shallow marine benthic infauna associated with the end-Ordovician extinction event, but the limited nature of the study area necessitates caution in making firm conclusions. Many other factors, biological, environmental and geological, may have contributed to the pattern observed.

(2) The occurrence of low ichnofabric indexes in both Hirnantian and Rhuddanian strata indicates that the bioturbation levels are not artefacts of stratigraphic dilution, and that they may be a consequence of ecological stresses associated with the extinction event. However, due to variations in tectonic activity, a reduction in sedimentation rate during the transgression is not consistent across the Welsh Basin (see e.g. Davies et al. 1997), so this interpretation may not be applicable regionally.

(3) The Welsh Basin is an excellent area for observing ichnological and ecological changes during this time interval, despite variations in the quality and extent of outcrop, and should be studied further to obtain a fuller picture of regional patterns.

(4) Other late Ordovician shallow-water successions should be examined to determine whether their ichnological patterns are comparable with those of the Welsh Basin, and whether the extinction event had a global impact on bioturbation.

Acknowledgements. Andy Rees and Rob Raine (University of Birmingham) are thanked for their assistance with fieldwork and sample measurement, and the critical comments and advice of Paddy Orr and 2 anonymous reviewers are gratefully acknowledged.

\section{LITERATURE CITED}

Barclay WJ, Davies JR, Humpage AJ, Waters RA, Wilby PR, Williams M, Wilson D (2005) Geology of the Brecon district-a brief explanation of the geological map. Sheet Explanation of the British Geological Survey, 1:50000 Sheet 213 Brecon (England and Wales), British Geological Survey, Keyworth, Nottingham

Brenchley PJ, Marshall JD, Carden GAF, Robertson DBR and others (1994) Bathymetric and isotopic evidence for a short-lived Late Ordovician glaciation in a greenhouse period. Geology 22:295-298

Brenchley PJ, Marshall JD, Underwood CJ (2001) Do all mass extinctions represent an ecological crisis? Evidence from the Late Ordovician. Geol J 36:329-340

British Geological Survey (2005a) Builth Wells. England and Wales Sheet 196. Solid and drift geology, 1: 50 000. British Geological Survey, Keyworth, Nottingham
British Geological Survey (2005b) Brecon. England and Wales Sheet 213. Bedrock and superficial deposits, 1:50000. British Geological Survey, Keyworth, Nottingham

Buatois LA, Jalfin G, Aceñolaza FG (1997) Permian nonmarine invertebrate trace fossils from southern Patagonia, Argentina: ichnologic signatures of substrate consolidation and colonization sequences. J Paleontol 71:324-336

Cocks LRM, Woodcock NH, Rickards RB, Temple JT, Lane PD (1984) The Llandovery series of the type area. Bull Br Mus (Nat Hist) Geol 38:131-182

Davies JR, Fletcher CJN, Waters RA, Wilson D, Woodhall DG, Zalasiewicz J (1997) Geology of the country around Llanilar and Rhayader. Memoir of the British Geological Survey, Sheets 178 and 179 (England and Wales). British Geological Survey, Keyworth, Nottingham

Droser ML, Bottjer DJ (1986) A semiquantitative field classification of ichnofabric. J Sediment Petrol 56:558-559

Droser ML, Bottjer DJ (1989) Ichnofabric of sandstones deposited in high-energy nearshore environments: measurement and utilization. Palaios 4:598-604

- Droser ML, Bottjer DJ, Sheehan PM (1997) Evaluating the ecological architecture of major events in the Phanerozoic history of marine invertebrate life. Geology 25:167-170

Einsele G (1996) Event deposits: the role of sediment supply and relative sea-level changes - overview. Sediment Geol 104:11-37

Ekdale AA, Bromley RG (1984) Sedimentology and ichnology of the Cretaceous-Tertiary boundary in Denmark: implications for the causes of the terminal Cretaceous extinction. J Sediment Petrol 54:681-703

Ekdale AA, Stinnesbeck W (1998) Trace fossils in CretaceousTertiary (KT) boundary beds in northeastern Mexico: implications for sedimentation during the KT boundary event. Palaios 13:593-602

Ekdale AA, Bromley RG, Pemberton SG (1984) Ichnology: trace fossils in sedimentology and stratigraphy. SEPM Short Course 15, Society of Economic Paleontologists and Mineralogists, Tulsa, OK

- Fraiser M, Bottjer DJ (2005) Restructuring in benthic levelbottom shallow marine communities due to prolonged environmental stress following the end-Permian mass extinction. C R Palevol 4:583-591

McCann T (1990) Distribution of Ordovician-Silurian ichnofossil assemblages in Wales-implications for Phanerozoic ichnofaunas. Lethaia 23:243-255

McIlroy D (2004) Some ichnological concepts, methodologies, applications and frontiers. In: McIlroy D (ed) The application of ichnology to palaeoenvironmental and stratigraphic analysis. Spec Pub 228, Geological Society, London, $\mathrm{p} 3-27$

McIlroy D (2007) Lateral variability in shallow marine ichnofabrics: implications for the ichnofabric analysis method. J Geol Soc (Lond) 164:359-369

> Orr PJ (2001) Colonization of the deep-marine environment during the early Phanerozoic: the ichnofaunal record. Geol J 36:265-278

Pemberton SG, Spila M, Pulham AJ, Saunders T, MacEachern JA, Robbins D, Sinclair IK (2001) Ichnology and sedimentology of shallow to marginal marine systems: Ben Nevis and Avalon Reservoirs, Jeanne d'Arc Basin. Short Course Notes Vol 15, Geological Association of Canada, St. John's, Newfoundland

Pruss S, Bottjer DJ (2004) Early Triassic trace fossils of the western United States and their implications for prolonged environmental stress from the end-Permian mass extinction. Palaios 19:551-564

Pruss S, Fraiser M, Bottjer DJ (2004) Proliferation of Early 
Triassic wrinkle structures: implications for environmental stress following the end-Permian mass extinction. Geology 32:461-464

Rodríguez-Tovar FJ (2005) Fe-oxide spherules infilling Thalassinoides burrows at the Cretaceous-Paleogene (K-P) boundary: evidence of a near-contemporaneous macrobenthic colonization during the K-P event. Geology 33: 585-588

Rodríguez-Tovar FJ, Uchman A (2004a) Ichnotaxonomic analysis of the Cretaceous/Palaeogene boundary interval in the Agost section, south-east Spain. Cretac Res 25: 635-647

Rodríguez-Tovar FJ, Uchman A (2004b) Trace fossils after the K-T boundary event from the Agost section, SE Spain. Geol Mag 141:429-440

Schofield DI, Davies JR, Waters RA, Wilby PR, Williams M, Wilson D (2004) Geology of the Builth Wells district-a brief explanation of the geological map. Sheet explanation of the British Geological Survey, 1:50 000 Sheet 196 Builth Wells (England and Wales). British Geological Survey, Keyworth, Nottingham

Sheehan PM (2001) The Late Ordovician mass extinction. Annu Rev Earth Planet Sci 29:331-364

Temple JT (1988) Ordovician-Silurian boundary strata in Wales. Bull Br Mus (Nat Hist) Geol 43:65-71

Twitchett RJ (1999) Palaeoenvironments and faunal recovery

Submitted: October 8, 2007; Accepted: March 14, 2008 after the end-Permian mass extinction. Palaeogeogr Palaeoclimatol Palaeoecol 154:27-37

Twitchett RJ, Barras CG (2004) Trace fossils in the aftermath of mass extinction events. In: McIlroy D (ed) The application of ichnology to palaeoenvironmental and stratigraphic analysis. Spec Pub 228, Geological Society, London, p 397-418

Twitchett RJ, Wignall PB (1996) Trace fossils and the aftermath of the Permo-Triassic mass extinction: evidence from northern Italy. Palaeogeogr Palaeoclimatol Palaeoecol 124:137-151

Uchman A, Bubík M, Mikuláš R (2005) The ichnological record across the Cretaceous/Tertiary boundary in turbiditic sediments at Uzgrun (Moravia, Czech Republic). Geol Carpathica 56:57-65

Wignall PB, Morante R, Newton R (1998) The Permo-Triassic transition in Spitsbergen: $\delta^{13} \mathrm{C}_{\text {org }}$ chemostratigraphy, Fe and S geochemistry, facies, fauna and trace fossils. Geol Mag 135:47-62

Williams A, Wright AD (1981) The Ordovician-Silurian boundary in the Garth area of southwest Powys, Wales. Geol J 16:1-39

Woodcock NH, Smallwood SD (1987) Late Ordovician shallow marine environments due to glacio-eustatic regression: Scrach Formation, Mid-Wales. J Geol Soc (Lond) 144: 393-400

Proofs received from author(s): May 23, 2008 